\title{
Gustav Johannsen i Magdeburg fæstning i 1879
}

ved RENÉ RASMUSSEN

Gustav Johannsen kom i sin tid som redaktør af Flensborg Avis til at afsone tre frihedsstraffe. To fængselsstraffe for fornærmelser på henholdsvis én og to måneder, som han afsonede i Glückstadt fængsel i 1876 og 1878, og én fæstningsarrest på tre måneder for majestætsfornærmelse, som han afsonede på fæstningen i Magdeburg i 1879. Frihedsstraffene mod danske journalister og redaktører var hyppige $\mathrm{i}$ årene mellem 1864 og 1914, og fra sidst $\mathrm{i} 1870$ 'erne blev de ofte afsonet under forhold, der var nedbrydende for helbredet. Fæstningsarrest var dog en frihedsstraf, der afsonedes under mildere former end simpelt fængsel. Oplevelserne bag tremmer nedskrev Gustav Johannsen senere $i$ erindringsform $i$ en notesbog, som han gav titlen »Fængselsliv«. Beretningen fra Magdeburg er aldrig tidligere blevet offentliggjort. Det kan skyldes, at den aldrig blev fuldført. Den slutter temmelig brat. Beretningen fortæller detaljeret om de forhold, de danske redaktører i Nordslesvig var underkastet som politiske fanger i datidens Tyskland. Den er skrevet med Gustav Johannsens typiske lune og sans for at gengive stemninger, men vidner også om, at fæstningsopholdet sled hårdt på hans nerver og tyngede på hans humør.

Det var i de første dage af marts måned 1879, at den mellem Preussen og Østrig afsluttede traktat af 11. oktober 1878 angående ophævelsen af Pragfredens artikel V, blev bekendt. Hvilket indtryk denne traktat gjorde i Nordslesvig, er det ikke stedet at beskrive nærmere; men det var denne traktat, der blev årsag $i$, at jeg atter forløb mig imod den preussiske presselov. Jeg blev af statsadvokaten anklaget for majestætsfornærmelse, og retten idømte mig 6 måneders fæstningsarrest. Det var en hård dom, men den var dog ikke så hård, som statsadvokaten havde ønsket den; han havde nemlig andraget på 1 års fængselsstraf. Når man føler sig aldeles uskyldig, og det gjorde jeg i dette tilfælde, er det så meget mere overvældende at høre statsadvokaten fremsætte sin frygtelige anklage og retten forkynde en hård dom. Min familie var naturligvis meget ulykkelig, og dette tyngede svært på mig. Jeg appellerede sagen, men også appelretten i Kiel fandt mig skyldig og stadfæstede Flensborg kredsrets dom.

$\mathrm{Nu}$ traf det sig så heldigt for mig, at kejser Wilhelm, hvem jeg 
havde fornærmet, og hans dronning den 11. juni samme år fejrede deres guldbryllup. Ved denne lejlighed blev forskellige til fængsel eller fæstning dømte personer i de under kejseren stående lande enten helt eller til dels benådede. Også jeg var imellem de lykkelige, men ikke hele straffen, kun halvdelen eftergaves mig, hvilket statsadvokaten meddelte mig i en skrivelse af 16 . juli.

Kort efter fik jeg befaling til at stille mig i fæstningen i Magdeburg i preussisk Sachsen hos kommandanten dersteds for at tiltræde de tre måneders fæstningsarrest. Den 30 . juli om eftermiddagen klokken 5 forlod jeg Flensborg; min familie græd, men det hjalp jo ikke, jeg måtte lystre statsadvokatens befaling. Også denne gang fulgte en stor flok venner med til banegården og ud til det nordslesvigske sporskifte, og så gik det videre med dampens vinger.

I den kupé, hvor jeg havde taget plads, sad foruden mig en alvorlig og stille tysker og en livlig ældre dansk herre. Begge havde af mine venners afskedshilsener, håndtryk og venlige tilråb fået en anelse om, hvem jeg var; danskeren forestillede sig også snart selv, men tyskeren mælede ikke et ord. Danskeren var fra Odense og på en forretningsrejse til den slesvigske marsk.

Han kunne ikke forstå, ytrede han, hvorfor jeg ikke forlod et land, hvor jeg måtte udstå forfølgelser og fængselsstraffe; men efter en længere samtale med mig syntes han dog at fatte, at der gives højere livsmål end det rent materielle velvære. I Jydbæk tog han afsked fra mig, og i hans sted fik jeg selskab af en ældre tysktalende herre, der ret snart indledte en samtale med mig og gav mig sit kort. Jeg var nødt til at gøre gengæld og nu vidste han også straks besked med, hvorfor jeg ville så langt syd på. Han var fra en af vesterhavsøerne og kendte godt til de nordslesvigske forhold. I Hamborg forlod også han mig.

Snart gik det med betydelig hurtighed videre i den klare måneskinsnat over Bergedorf, Büchen, Boizenburg, Hagenow, Ludwigsthal, Grabow og Wend. Warnow til Wittenberge. Her måtte jeg stige ud for at komme over i det tog, der over Seehausen, Sendal, Tangeshütte og Wolmirzt førte til Magdeburg. I måneskin er turen fra Hamburg til Wittenberge ret interessant, thi ved stationerne og næsten alle vegne langs med banen kan [man] nok se de smukke anlæg, hvorpå der unægteligt er anvendt megen flid, medens det ufrugtbare, flade land ikke kan kendes. I Wittenberge var det blevet lyst, og nu gik det i en fart til Magdeburg. Denne tur er også meget ensformet, 
store marker med sukkerroer er det sædvanlige syn, kvæg der græsser fredeligt på kløvermarken eller i engen, findes ikke på hele vejen. Magdeburg banegård er stor og smuk, men fæstningsværkerne gør ikke indtryk af, at man befinder sig i en preussisk fæstning af første rang. Omkring banegården ligger den smukkeste del af byen, med store brede gader; men det er også den nyeste del og gør derfor et godt indtryk på den fremmede.

Jeg tog ind i Kochs Hotel, der ligger lige tæt ved banegården. Klokken var hen imod 6 om morgenen; opvarteren som tog imod mig, så noget søvndrukken ud og syntes ikke rigtig at kunne forstå mit tysk, i det mindste spurgte han hvert øjeblik: »Was? « Jeg blev snart ked af hans evige "was? «, ikke fordi det var mig mere ubehageligt end et pibende »wie?«, men jeg var jo ikke oplagt til store forklaringer, hvorfor jeg til sidst råbte af alle kræfter: "Geben Sie mir ein Zimmer und Kaffe, De flynder!«

Det hjalp, snart kom jeg ind i et smukt værelse, og jeg havde knapt vasket mit ansigt og mine hænder, så kom »flynderen « med kaffe. Efter kaffen gjorde jeg straks en lille spadseretur $i$ den ny del af byen, gik igennem Kronprinzstraße til Kaiserstraße og fra denne forbi Ulrichskirche til Breiteweg. Kaiserstraße og Breiteweg er lange, brede og smukke gader, men de ligger også $\mathrm{i}$ den smukkeste og til dels $\mathbf{i}$ den nyeste del af byen, uden disse gader ville Magdeburg gøre et dårligt indtryk på den fremmede. Påfaldende er for den fremmede, at alle kirker er forsynede med to tårne; magdeborgerne forklarer det som et tegn fra gammel tid på, at byen har været sæde for en ærkebiskop.

Da jeg kom tilbage til hotellet, var der kommet liv i dets beboere, og snart opvartedes jeg med en frokost, der i sammenligning med, hvad man hos os forstår under frokost var såre tarveligt, men min sult blev jeg dog herre over. For at orientere mig i byen, bladede jeg i adressebogen og så efter $i$ en plan over Magdeburg, og snart fandt jeg, hvor kommandanten, hans excellence general von Massow boede, hos hvem jeg skulle melde mig. Kommandantens navn mindede mig om hin amtmand i Aabenraa, der under Christian den Sjette gjorde sig al mulig umage for at bilde sin konge og landsherre ind, at aabenraaerne var bedst tjent med tysk gudstjeneste, endskent daværende provst Schmidt dersteds afgav den erklæring: »daß in der Stadt und Kirchspiel Apenrade der größte Haufe der teutschen Sprache nicht völlig kundig ist.« Hin amtmand hed også von Massow. 
Jeg fandt også snart citadellet, hvilket fra næste dag af i 3 måneder skulle tjene mig som opholdssted, hvorfor jeg endnu samme dag gik hen og beså denne vigtige del af fæstningen. Det ligger på en ø i Elben og er omgivet af høje gammeldags mure. En smuk bro fører fra byen over Elben til øen. Magdeborgernes stolthed er den smukke domkirke, der imponerer den fremmede, endskønt en kritisk iagttager nok kan finde et $\mathrm{og}$ andet at dadle ved dens to tårnes tilstand.

Endnu en nat sov jeg som fri mand indenfor Magdeburgs mure. Den 1. august meldte jeg mig hos kommandanten, der tog meget forretningsmæssigt imod mig og sagde, at jeg kom til at finde mig i at følge de forholdsregler, som var foreskrevne for "Festungs-Stubungsfangene«. Han lod mig vide, at jeg også havde at melde mig hos pladsmajoren, der bor på citadellet, hvorfor jeg kunne vente med at gøre ham min opvartning til om eftermiddagen før klokken 7, men til det klokkeslæt måtte jeg også melde mig, når jeg ønskede, at den dag skulle regnes med $\mathrm{i}$ mine 3 måneder.

Klokken 5 om eftermiddagen tog jeg en droske og kørte ud til citadellet. Jeg lod mig melde hos pladsmajoren, blev modtaget af denne og efter en kort samtale overleveret til fangevogteren, »Feldwebel« Bümann. Pladsmajoren gav mig dog først nogle forholdsregler og sagde mig, at jeg ville få det dårligste værelse, der findes i fængslet, men han befalede samtidig "Feldwebelen « at give mig et bedre værelse, når om nogle dage overvagtmester Klatt fra Haderslev forlod fængslet. "Feldwebelen « førte mig nu over til fængslet, der er en ussel bindingværksbygning, omgivet af et højt plankeværk, som næsten gør det umuligt for fangerne i stueetagen at se ud på den store exercerplads foran huset. Jeg fik nu rigtignok også et usselt værelse, der ligger ud imod volden og hvorfra der ikke er mindste udsigt. Der stod en almindelig soldaterseng i værelset, et brunt malet klædeskab, et usselt bord og to træstole, som man hos os ikke har dårligere $i$ et karlekammer. Et vaskebord måtte først lånes $i$ et andet værelse, hvorved jeg straks opdagede, at der endnu stod to værelser ledige, der begge var bedre end mit. Hvorfor fik jeg da det dårligste værelse?

Jeg havde kun lige fået min kuffert og øvrige sager stillet på passende pladser i mit værelse og af "Feldwebelen « modtaget instruktionen for fangerne til gennemlæsning, så kom overvagtmester Klatt fra Haderslev, ind til mig og bød mig meget venligt velkommen. Det var i fritiden fra 4 til 7, og da jeg [bød] den venlige medfange at sidde ned, gjorde han det, og snart fik vi en samtale i gang om fængselsli- 
vet, så jeg allerede den første dag blev indviet i fængslets hemmeligheder. Jeg var så lykkelig at kunne byde min medfange en cigar og et glas vin, hvilken sidste jeg havde fået med fra Flensborg, nogle venner havde foræret mig den. Klokken 7 gik »Feldwebelen« og lukkede både for stueetagen og første sal, men de enkelte fængselsdøre lukkede han ikke, hvilket jeg, der i Glückstadt var blevet vant til at blive indelukket i mit værelse, fandt særdeles behageligt, så jeg den første aften bildte mig ind, at jeg slet ikke var i fængsel, om end jernstængerne for vinduerne noksom mindede mig om, at jeg var fange. Klokken 11 slukkede jeg min lampe (fangerne tør ikke længere brænde lys), og så gik jeg i seng. Jeg tænkte på mit hjem og gjorde sammenligninger mellem Magdeburg og Glückstadt, indtil jeg sov ind.

Den 2. august, min fødselsdag, vågnede jeg om morgenen klokken 5. Min første tanke var: Hvorledes ville min kone, børnene og min gamle moder være stemte, når de $\mathrm{i}$ dag ikke kunne bringe mig deres lykønskninger i dagens anledning? Vejret tegnede til at blive meget smukt, i det mindste var den smule himmel, som jeg kunne se fra mit værelse, meget klar. Skildvagten mærkede snart, at jeg var stået op, og nysgerrig efter at se, hvad jeg bestilte så tidlig, kom han hen til mine vinduer og gloede ind til mig. Jeg råbte: "Guten Morgen!« og åbnede et vindue og ville til at tale et par ord med mennesket, men fyren forsvandt bag hjørnet af fængselsbygningen og kom ikke igen. Klokken 6 kom »Feldwebelen « og ordonnansen, der blev lukket op og jeg fik min kaffe. Overvagtmesteren kom også snart frem, endvidere en forhenværende preussisk "Hauptmann «, der boede på 1. sal, de andre fanger rørte sig ikke endnu. Der blev nu redt seng og fejet ud hos mig, medens jeg fik mig en lille samtale med "Feldwebelen « og overvagtmesteren.

Snart kom der også et par breve til mig, lykønskninger i anledning af min fødselsdag, og senere modtog jeg 5 telegrammer, ligeledes indeholdende lykønskninger. Det opmuntrede mig meget. Klokken 9 kom overvagtmesteren og tog mig med ud at spadsere i den berømte (det vil sige under [i.e. blandt] fangerne) Pæreallé på citadellet, i hvilken spadserevejen for »Stubungsfangene«, som vi kaldtes, er betegnet med tavler med den nødvendige påskrift og kommandantens navn under. Snart kom også en tredje fange ud i alléen, jeg blev forestillet for ham og erfarede, at han var student og indespærret i "fugleburet", som fangerne kaldte fængselsbygningen, på grund af en duel. Stu- 
denten var en lystig ung mand, der allerede om formiddagen drak flere halve liter bajersk $ø$.

Vi var i det hele 10 »Stubungsfangene«, hvoraf 4 boede i stueetagen, 4 på første sal og $2 \mathrm{i}$ kvistværelser. Overvagtmesteren underrettede mig om, hvilken forseelse hver enkelt havde begået, og det interesserede mig meget at erfare. Da vore værelser var betegnede med nummer, så vil jeg følge talrækken ved gengivelsen af de meddelelser, jeg modtog af min venlige medfange om beboerne af "fugleburet."

I nummer 1 sad en ung til menig degraderet preussisk officersaspirant. Han var idømt 5 års fæstningsarrest for majestætsfornærmelse og havde allerede siddet 1 år. Det var en pyntelig ung fyr, han gik med lorgnet og holdt mest af at omgås officererne. Han havde, da efterretningen om, at Nobeling havde skudt på kejser Wilhelm sagt: "Unkraut vergeht nicht! « Dette ord fældede ham og bragte ham på fæstningen. Fyren syntes dog ikke at have tabt lysten til at leve og skal endogså i "fugleburet" have forsøgt sig i kærlighed, idet han nemlig gjorde kur, så godt det lod sig gøre i hans stilling som fange, til datteren af en på citadellet boende officer; men det blev opdaget og han blev forhindret $i$ at fortsætte sit lige begyndte kærlighedsforhold.

I nummer 2 sad overvagtmesteren, der på grund af en falsk rapport var kommen på fæstningen. Han fandt sig kun dårligt i fængselslivet og sørgede meget over sin ulykke, og det var en ynk at se ham græmme sig.

I nummer 3 sad atter en ung til menig degraderet preussisk officersaspirant. Han var idømt 3 års fæstningsarrest for majestætsfornærmelse og havde ligeledes allerede siddet 1 år. Han var ikke så pyntelig som sin kammerat, havde lært mere på gymnasiet, men var vistnok meget let. Han havde på samme tid som den anden gjort sig skyldig i majestætsfornærmelse, idet han, da han ville købe en revolver til seks skud og regimentsbøssemageren frarådede ham det, havde sagt: "Åh, to skud er jo for tiden jo også tilstrækkeligt; ét for Wilhelm og ét for mig! « Den unge mand havde indrettet sit værelse til et rigtigt fuglebur, 5-6 fugle fløj frit omkring deri og kunne hvile sig foruden på møblerne på nogle store tørrede buske, der stod opstillede i værelsets 4 hjørner. At hans bord, seng og øvrige møbler besudledes af fuglene, generede ham ikke; han selv lå for det meste kun klædt i skjorte og underbenklæder på sin seng og læste.

I nummer 4 sad jeg, og 5 og 6 stod ledige.

I nummer 7 sad en ung officer, der ved indøvelsen af en rekrut 
Gustav Johannsen (1840-1901). I 1869 grundlagde han Flensborg Avis og var en tid lang også avisens redaktor. Det var en ikke ufarlig bestilling $i$ Sonderjylland $i$ årene mellem 1864 og 1920. Heller ikke Gustav Johannsen slap for lange fangselsophold. Billedet her er samtidigt med opholdet $i$ Magdeburg fæstning 1879. Foto: Arkivet ved Dansk Centralbibliotek for Sydslesvig.

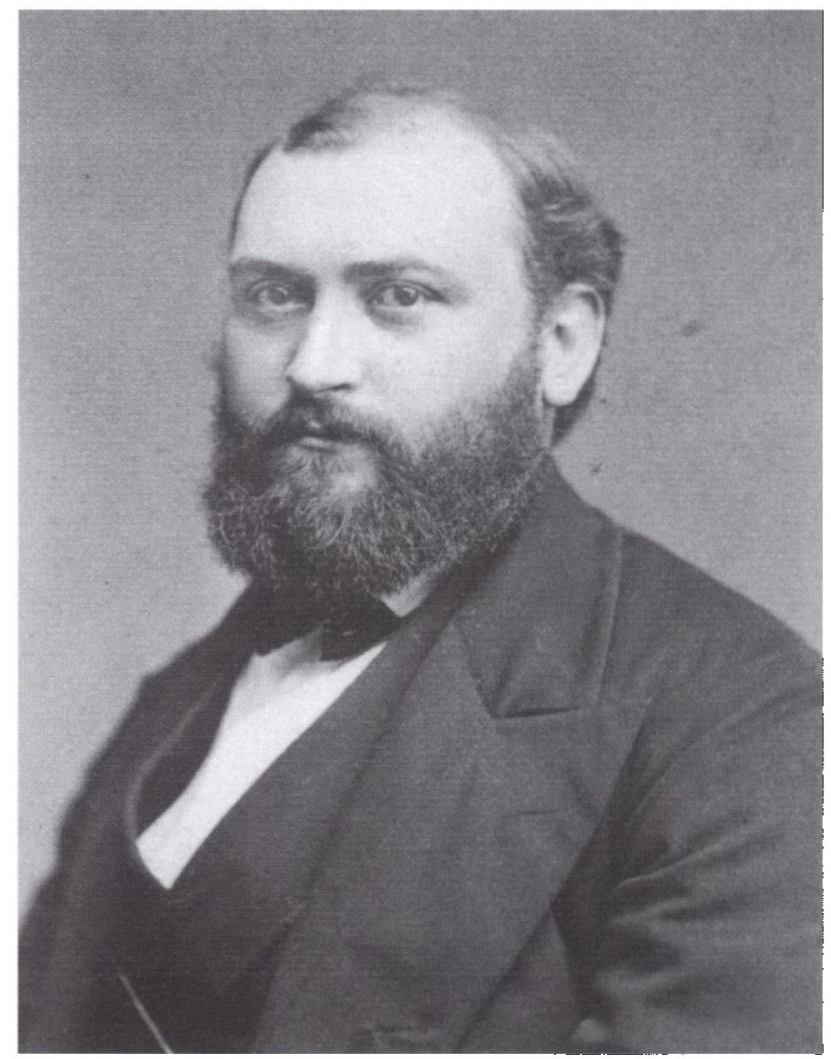

havde forløbet sig således, at han i sin vrede sårede staklen med sin sabel. Han var idømt 3 måneders fæstningsarrest, hvilke han benyttede til at lære fremmede sprog, i hvilken anledning en lærer fra byen to gange ugentlig kom til ham $i$ »fugleburet.«

I nummer 8 sad en forhenværende "Hauptmann«, der var idømt 5 års fæstningsarrest, fordi han $i$ en duel havde dræbt sin modstander.

I nummer 9 sad en student, der var idømt 3 års fæstningsarrest, ligeledes for $i$ en duel at have dræbt sin modstander. Han lod til at føle sig meget trykket af den ulykkelige historie, var meget flittig og overordentlig forekommende og venlig.

I nummer 10 sad den lystige student, der slog tiden ihjel med at drikke øl. Han havde også duelleret, men ikke skadet sin modstander videre, hvorimod han bar betydelige tegn i ansigtet på ubehagelige kårdehug. Han var også kun idømt 4 ugers fæstningsarrest. 
Nummer 11 og nummer 12 var ikke beboede.

I nummer 13 sad en ung løjtnant, der var idømt 4 måneders fæstningsarrest, fordi han havde nægtet at lystre en foresat. Det var et stille og sygeligt udseende menneske.

I nummer 14 sad en brunsvigsk husarofficer, en smuk ung mand, stolt og tilbageholdende. Han havde duelleret og skulle sidde 4 måneder, hvilket han var meget ked af.

Flere værelser fandtes ikke $\mathrm{i}$ »fugleburet«, men deres antal var jo også tilstrækkeligt.

$\mathrm{Nu}$ vidste jeg altså besked med mine medfanger. Overvagtmesteren var så venlig efter disse meddelelser at følge med på mit værelse for at drikke et glas med mig af den vin, som min ven Colding ${ }^{1}$ samme dag havde sendt mig, og også et par andre medfanger tog $i$ anledning af min fødselsdag imod min indbydelse og tømte om eftermiddagen et par flasker på mit og deres velgående. Det skete i fritiden fra 4 til 7 , men præcis klokken syv kom fangevogteren for at lukke og nu gik hver til sit værelse. Jeg skrev endnu til min hustru og fortalte hende, at jeg havde det godt.

De mange depecher, jeg modtog den dag, vakte opsigt på citadellet, ikke mindst på grund af de forskellige adresser, thi den ene var adresseret til redaktør Gustav Johannsen, den anden til Oldermanden for Skt. Knudsgildet, den tredje til bestyrelsesmedlem af Spare- og Lånekassen for Flensborg og Omegn, den fjerde til formanden for "Ydun" og den femte til direktøren for Flensborg Aktie-Mejeri-Selskab. ${ }^{2}$ Telegrafbudet mente, at afsenderen kunne have sparet meget, når de ikke havde valgt så lange titel-adresser, men han havde ingen anelse om, at mine venner ikke brød sig om at spare en mark, når de troede at kunne glæde og more mig.

Jeg havde snart levet mig ind i de nye forhold, thi i hovedsagen lignede den ene dag den anden. Om morgenen klokken 6 kom fangevogteren og lukkede op, ordonnansen bragte kaffen og begyndte at rede seng og feje ud, først hos den, der stod tidligst op, og iblandt dem var jeg. Klokken 8 kom posten, den bragte mig Flensborg Avis, Nationaltidende, Fædrelandet og Magdeburgische Zeitung morgenblad, og var der indløbet breve til mig, fik jeg dem også med denne post. Klokken 9 blæstes eller trommedes ved vagten til tegn på, at vi kunne spadsere i Pærealléen, og klokken 11 trommedes eller blæstes vi atter ind $\mathrm{i}$ »fugleburet«. Så gik atter fangevogteren og ordonnansen og dørene lukkedes, skildvagten fik nøglerne og befaling til kun at lukke 
op for pladsmajoren og kommandanten, og nu forst fik han travlt med at passe på os, idet han idelig gik omkring huset og gloede ind ad vinduerne til de fanger, der boede i stueetagen. Klokken hen imod 1 kom fangevogteren og ordonnansen atter tilbage, den sidste med så mange portioner middagsmad, som han kunne bære, resten hentede han straks efter og bragte også snart eftermiddagskaffen. Klokken 2 forsvandt de to vigtige personer igen, og vi blev atter indelukkede til klokken 4 . Så blæstes eller trommedes der atter ved vagten, dørene lukkedes op, og fangerne havde da indtil klokken 7 atter fri adgang til Pærealléen. Lidt før 7 bragte ordonnansen aftensmaden, klokken 7 blæstes eller trommedes der atter, fangevogteren lukkede dørene, gav skildvagten nøglerne og fjernede sig for ikke at komme igen før næste morgen klokken 6. I fulde 11 timer hørte og så vi ikke andre end de forskellige skildvagter, der hver anden time skiftede.

Der er noget uhyggeligt $\mathrm{i}$ at vide sig bevogtet af skildvagter, som går og lusker og agter på enhver bevægelse, man gør. Altid at se på et gammelt plankeværk, når man ser ud af vinduerne, er også grumme kedeligt; men hvad var vel alt dette imod Glückstadt? ${ }^{3}$ Mennesket er dog næppe i stand til altid at trøste sig over dårlige livsvilkår ved at sammenligne dem med endnu dårligere; i det mindste kunne jeg ikke altid berolige mig med at gøre sammenligninger mellem Magdeburg og Glückstadt. Det ærgrede mig navnlig tit, at jernstængerne i Magdeburg var meget bredere og tættere, om end ikke så kolossale som i Glückstadt. Jeg sad jo dog i en kongelig preussisk fæstning og hørte med til de fineste preussiske fanger, og alligevel bevogtede man mig strengere end i det simple fængsel i Glückstadt?!

I instruktionen for stuefangerne stod, at kommandanten på ansøgning tillod fangerne at spadsere $i$ byen, dog kun 3 timer ad gangen og ikke for tit. Den 6. august fik jeg første gang tilladelse til at benytte mine tre eftermiddagsspadsereture til en lille udflugt $i$ byen, dog turde jeg ikke komme på offentlige spadseregange, banegården og de mange forlystelsessteder, der findes i og omkring byen, heller ikke i hoteller og restauranter, og som en meget vigtig bestemmelse fremhævedes, at jeg måtte være hjemme igen præcis klokken 7 . Johanniskirkeuret betydedes som det, jeg kunne rette mig efter. Da overvagtmesteren den næste dag havde udstået sin straf, ansøgte han om tilladelse til at sige farvel i de timer, jeg spadserede i byen, hvilket også tilstodes ham. Vi gik nu sammen ud og kom også samtidig tilbage til citadellet. Om det nu end ikke kan more ret længe og ofte at gå omkring i en by som Magdeburg 
og se på butikker, så var det dog altid en forandring fra livet på citadellet $o g$ man folte sig i de tre timer som fri mand.

Den næste dag flyttede jeg ind $i$ det hidtil af overvagtmesteren beboede værelse nummer 2. Dette værelse lå ud til exercerpladsen, og når jeg stod op på en stol, kunne jeg se over plankeværket og iagttage, hvad der foregik på den store plads, der indesluttedes af det såkaldte "geværhus", hvori der opbevaredes tusinder og atter tusinder af geværer. "Kanonhuset«, hvori der gemmes over 100 kanoner, nogle haver, der hører til officersboligerne, og vort usle "fuglebur«, der er den dårligste bygning på hele citadellet. Hvor ofte har jeg ikke stået på en stol og set ud gennem jerngitteret! Exercitsen var sædvanligt forbundet med megen råben og skælden, hvoraf fangerne ikke sjældent forstyrredes $\mathrm{i}$ deres alvorlige betragtninger af fængselslivet eller ved skrivning og læsning. I numrene 1, 2 og 3 sad altså fra nu af $i$ en række 3 majestætsfornærmere, men de to unge soldater var ikke noget passende selskab for mig, og vi talte derfor sjældent med hverandre. Den ene gik meget frem og tilbage i sit værelse og fløjtede, endskønt det var forbudt at fløjte, synge eller gøre larm. Den anden hørte jeg ofte pludselig bryde ud $i$ en høj latter; han lå nemlig i underbenklæderne på sin seng og læste Fritz Reuters Ut mine Festungstid. Jeg ynkedes [ved] de to unge mennesker, thi der var jo al udsigt til, at de ville blive unyttige lemmer af det menneskelige samfund. Med 19 år at blive idømt 3 respektive 5 års fængselsstraf! Det forekom mig at være en meget hård skæbne, især når jeg tænkte på de letsindige ytringer, der havde forvoldt de unge menneskers ulykke.

En formiddag kom jeg ind i Pærealléen og [mødte] der allerede min nye medfange fra nummer 3 i selskab med en smuk gammel herre; jeg hilste, og den unge mand forestillede mig for - sin bedstefader. Bedstefaderen, en gammel købmand fra Schwartzburg-Rudolphstadt, var meget venlig og indledte straks en samtale med mig, fortalte, at han havde været i Danmark og København, fundet mit fædreland - man var nemlig i citadellet så oprigtig at kalde mig "der Däne « - særdeles smukt og opholdet meget behageligt. Den gamle mand havde af kommandanten fået tilladelse til i cirka otte dage hver for- og eftermiddag at besøge sin sønnesøn i fritimerne, og denne tilladelse benyttede han også troligt. At han tog sig sønnesønnens ulykke meget nær, kunne han ikke helt holde skjult, endskønt han bestræbte sig for at tage sagen med ro.

Dagene gik deres langsomme gang og afskedstimen oprandt, men 
den skulle blive til en sand glædesdag for den gamle mand og hans sønnesøn. Tidlig på formiddagen, endnu forinden fritimen, kom pladsmajoren med hastige skridt ind $\mathrm{i}$ fugleburet, gik ind $\mathrm{i}$ nummer 1 og straks efter også i nummer 3, fjernede sig derpå lige så hurtigt og gik tilbage til sin bolig. Han var dog kun lige gået ud af vor port, så stormede begge mine unge medfanger ud på forstenen, råbte $\mathrm{i}$ munden på hinanden: "gratuliere! gratuliere!«, bankede snart på hos den ene, snart hos den anden af deres medfanger og tilråbte os: „Begnadigt! begnadigt!« Deres krigsherre havde benådet dem og givet dem tilladelse til atter at træde ind i militærtjenesten, dog som menige og hver ved et nyt regiment. Der blev nu en stor larm i det stille hus, thi alle fanger delte de to unge menneskers glæde, ja, selv fangevogterne tog del i den. Snart stormede de to unge mennesker ud i byen, den ene for at opsøge sin gamle bedstefader, den anden for at telegrafere til sine forældre. Et par timer efter kom de tilbage, og nu begyndte de under sang og lystige udbrud at pakke deres sager ind, thi de havde tilladelse til at forlade fængslet, så snart de ville. Den dag var der ikke megen ro $i$ "fugleburet«, de unge mennesker gik og kom, pakkede ind og ud og atter ind, indtil de sent om aftenen endelig med kister og kasser læssede på en vogn forlod citadellet, ledsagede af de tilbageblevnes varmeste ønsker for deres fremtid.

Jeg beboede nu stueetagen helt ene, men havde et svagt håb om, at den preussiske admiral Batsch muligvis kunne blive min nabo i et af de forladte værelser. Admiralen var som bekendt idømt seks måneders fæstningsarrest $i$ anledning af »Grosser Kurfürsts « undergang ved den engelske kyst. Han kom også til Magdeburg, beså vort "fuglebur«, men - foretrak at sidde i selve byen Magdeburg. At vi fanger ikke syntes om, at admiralen behandledes anderledes end vi, og at vi betragtede dette som en umotiveret hensyntagen, vil man næppe tage os ilde op; måske gjorde det os mest ondt, at vi måtte undvære den adspredelse, som admiralens komme og de med hans nærværelse af os som rimeligt forudsatte besøg etc. ville have givet os. Kort sagt: vi var meget utilfredse med den måde, hvorpå man berøvede os en forventet adspredelse. At vor utilfredshed ikke formindskedes, da admiralen efter 14 dages forløb blev benådet, forekommer mig at være letforståeligt; men vi - måtte roligt finde os deri.

Studenten og jeg sluttede os til hinanden, og da han ikke stod sig godt med officererne, så spadserede vi altid i to afdelinger: Officererne udgørende den ene større og studenten og jeg den anden mindre 
afdeling. I Pærealléen stod en meget lang bænk, og det var en afgjort sag, at når den ene afdeling havde taget plads på den, så holdt den anden sig fjernt fra den, endskønt den gav plads for alle fanger. På grund af en dårlig fod, hvori jeg i et par måneder led en hel del smerter, og den store varme $i$ august og en del af september, holdt jeg ikke meget af at gå, men passede godt på at blive den første på bænken, hvorfor officererne ofte måtte vandre hele timer frem og tilbage uden at få lejlighed til at benytte hvilepladsen. "Der Däne hat wieder die Festung eingenommen!« sagde embedsmændene på citadellet leende til hverandre, når de så mig sidde på bænken, og det morede dem meget, når de efter flere timers forløb atter kunne meddele hverandre: »Der Däne behauptet noch immer die Festung!« En af disse embedsmænd havde gjort krigen 1864 med og kunne endnu sige "god dag, min ven! " og "min smukke pige«, hvilket han fortalte med en vis stolthed. Kontoret, hvor disse herrer arbejdede, lå i Pærealléen, lige over for vor berømte bænk, hvilket ikke sjældent gav anledning til, at en eller anden af dem passiarede lidt med os fanger.

Den 26. august om eftermiddagen, lidt efter at vi havde spist til middag, kom pladsmajoren, fulgt af en ældre herre med gråt skæg, ind til mig og spurgte, hvor længe jeg endnu forblev på fæstningen, og da han erfarede, at jeg først rejste om rigeligt to måneder, henvendte han sig til sin ledsager med de ord: "Ja, så vil De så længe komme til at bo i nummer 3.« Den gamle herre forestillede sig nu som redaktør Dr. Guido Weiss ${ }^{4}$ fra Berlin, forklarede, at han havde bedt pladsmajoren om at få mit værelse, når det ikke var beboet, da han fra et tidligere ophold $\mathbf{i}$ »fugleburet « kendte lokaliteterne og holdt mit værelse for det bedste. Han var idømt 4 måneders fæstningsarrest for fornærmelse imod kronprinsen af Tyskland, fordi han, den gang kronprinsen stadfæstede blikkenslager Hödels dødsdom, havde skrevet om »die Wiedere[le]bung des Beils«. Dr. Weiss er en af de gamle tyske demokrater fra 1848, har tidligere været medlem af det preussiske deputeretkammer og lever i Berlin som publicist. ${ }^{5}$

Som kolleger og de to eneste beboere $i$ stueetagen blev vi snart bekendte med hinanden, og jeg havde megen glæde af min daglige omgang med den hæderlige, erfarne og kundskabsrige mand. Dertil kom, at han tillige var en god kammerat, fuld af livsappetit og resigneret. Han har et klart øje for de brøst, hvoraf det tyske statslegeme og det tyske folk lide, er retfærdig imod sine modstandere og fremmede nationer, følger ganske udmærket dagens begivenheder og lever i 
håbet om kommende bedre tider for de forskellige europæiske folkeslag. Med ham kunne jeg tale et fornuftigt ord om politik og lignende ting, hvilket var mig umuligt med studenten, der fuldkommen levede i den "Grössenwahn«, som man i politisk henseende træffer på hos så mange tyskere. Når vi, doktoren og jeg, søgte om tilladelse til at gøre en spadseretur $\mathbf{i}$ byen, så gjorde vi det altid samtidig og fulgtes også altid ad, hvilket gjorde mig disse fritimer meget behageligere end før.

En dag vovede vi at gå ind i en restauration tæt ved broen, der fører fra byen over Elben til citadellet, men vi havde kun lige taget plads og fået hver et glas øl, så hviskede doktoren til mig: "Majoren kommer! « Rigtig, pladsmajoren kom gående lige imod restaurationen, vi vendte ham hurtigt ryggen til, men han gik forbi uden at se os. Vi gik aldrig mere ind i den restauration!

Vore oppassere eller »ordonnanser«, som de kaldtes, voldte os en hel del bryderier. Min første oppasser var en polak, der kun dårligt forstod tysk, men des bedre var han til at snyde mig. Alt, hvad han købte til mig, var betydeligt dyrere, end jeg takserede det til, og jeg indskrænkede mig derfor så meget som muligt. En eftermiddag, da jeg kom ind fra min spadseregang i alléen, kom fangevogteren ind til mig med en vinflaske $\mathrm{i}$ hånden, og spurgte, om jeg kendte flasken. Jeg svarede, at den lignede en af de vinflasker, jeg havde fået med fra Flensborg, og nu fortalte han mig, at det meget rigtigt var min flaske og at oppasseren havde stjålet den fra mig, men at han havde opdaget det. Det var ikke den første flaske, fyren havde taget, tilføjede han, og nu skulle han meldes til regimentet. Jeg bad for staklen, men det hjalp ikke, fangevogteren påstod, at han ikke turde lade være med at skrive en melding $i$ anledning af tyveriet, og at han heller ikke ville have slyngelen længere $i$ huset, navnlig fordi han havde ham mistænkt for andre små tyverier og snyderier. Sagen blev rigtig meldt, og en skøn dag fik jeg en stor skrivelse fra regimentet, hvori jeg blev anmodet om at erklære, om jeg agtede at stille et andragende om at få polakken straffet eller ej. Jeg svarede, at jeg ikke ville andrage på staf for fyren, og dette frelste ham fra at komme på fæstningen, men 14 dages mørk arrest fik han alligevel.

Den ny oppasser var fra provinsen Sachsen, var en rigtig troskyldig bondedreng, der gerne gjorde mig det så behageligt som muligt og købte meget billigere end hans forgænger. Et svært uheld traf den ny oppasser et par uger efter, at han var tiltrådt sin tjeneste. Infanteri- 
lieutnanten havde givet ham 10 mark og anmodet ham om at kobe en flaske vin hos en bestemt vinhandler $i$ byen, og "Hauptmanden « havde givet ham 50 pfennig til at købe tobak for. Med disse 10 mark og 50 pfenning gik han nu ind i byen, købte en flaske vin, gik op på det kammer, hvor han logerede og lagde sig på sin seng for at sove lidt, da han havde en hel time, til han atter skulle være på citadellet.

I kammeret var der nogle andre soldater, som så, at han talte pengene og stak dem i sin brystlomme, førend han lagde sig til at sove. Da han vågnede, opdagede han straks, at pengepungen og pengene var borte, men også hans kammerater var forsvundet. Han kom nu grædende hjem og fortalte fangevogteren, hvad der var sket; denne gjorde en frygtelig larm og skældte ham ud, fordi han havde lagt sig til at sove. Jeg kom ud på forstuen og fik historien at vide, og da oppasseren jamrede over, at han, der i oktober skulle hjempermitteres, nu vist nok kom til at tjene et år længere, hvorover hans fattige forældre ville sørge meget, så gav jeg ham de penge, man havde stjålet fra ham, at han kunne betale officererne og så slippe for at blive meldt. Studenten kom også ned, og da han hørte, hvad der var sket, ville han absolut betale halvdelen af de penge, som jeg havde givet oppasseren. Dette burde jeg måske ikke have tilladt, thi da officererne, der modtog pengene af oppasseren, senere erfarede, at studenten og jeg havde givet ham dem, gav de pengene tilbage og nægtede at tage imod nogen erstatning; men sagen blev derfor også meldt til regimentet.

Da oppasseren imidlertid havde de bedste vidnesbyrd af sine foresatte og af en del af os fanger, blev han helt fri for straf, hvorover han var uendelig lykkelig, men så til gengæld plagede os i flere dage med at fløjte de vildeste melodier, når han sad på forstuen og blankede støvler eller børstede frakker og benklæder. Han blev hjempermitteret og der kom en ny soldat $i$ hans sted. Denne forstod aldeles ikke at rede sengen, d.v.s. tyste strået til rette i madrassen, hvilket var grumme kedeligt, da sengene allerede i forvejen ikke var de bedste til at sove i. Hans efterfølger, der var den sidste oppasser, jeg havde, var ikke dygtigere til at rede sengen, men var ellers en flink fyr.

En af disse oppassere spurgte mig en morgen, da han bragte mig kaffen og Magdeburgische Zeitungs morgenblad, om det virkeligt med det første ville komme til krig mellem Tyskland og Rusland. Jeg spurgte ham, hvorfor han spurgte således, og hans svarede, at der i hans kaserne var blevet fortalt, at kejser Alexander af Rusland havde fornærmet kejser Wilhelm og hans følge så blodigt under kejsermødet 
i Alexandrovo [3. september 1879], at selv et par "Zahlmeister «-Rendanter [regnskabsførere] af deres regiment havde sagt, det måtte komme til krig. Kejser Wilhelm havde måttet sove $i$ en ussel banegårdstilbygning og hans følge $\mathrm{i}$ jernbanevogne, og det kunne Tyskland dog ikke lade sig byde af de ukultiverede russere.

At det morede mig meget at få den brave preusser til at udtale sin hjertensmening og tolke mig den stemning, der herskede $i$ hans regiment, ja vist nok i hele den preussiske armé i den anledning, lod jeg ham naturligvis ikke mærke. Sikkert er, at alle preussere, fra den dannede til den udannede, betragtede kejser Wilhelms besøg hos kejser Alexander i den lille russiske grænseby som en ydmygelse og et tegn på, at Tyskland til trods for sin store magtstilling i Europa er nødt til at tage hensyn til andre stormagter, og dette ærgrede store og små, og hos disse sidste kom ærgrelsen til udbrud i de omtalte ytringer om en forestående krig med Rusland. Bismarcks rejse til Wien og den modtagelse, der blev ham til del af kejser Frantz Josef, dæmpede senere ærgrelsen over kejser Wilhelms modtagelse i Alexandrovo.

En formiddag blev vi stuefanger opmærksomme på, at nogle embedsmænd $\mathrm{i}$ forening med en del underofficerer rendte frem og tilbage på citadellets exercerplads, som om der var sket noget usædvanligt. Det var der også: En af militærstraffefangerne fra kasematfængslet havde forsøgt at undvige, men var snart blevet pågrebet igen på ydervolden. Dette flugtforsøg bragte staklen på tugthuset, så han fik det meget værre, end han havde haft det. I kasematfængslet på Magdeburgs citadel sidder sædvanligt mellem 100 og 200 militærstraffefanger, som de kaldes. Disse stakler må under bevogtning af underofficerer arbejde ved fæstningsværkerne og på citadellet, undertiden ret strengt, og dog er deres forseelser ofte ikke slemme, men den preussiske krigsret er streng.

Enkelte er såkaldte »Fahnenflüchtige«, folk, der ikke har stillet til den pligtige militærtjeneste, og iblandt disse er ikke få nordslesvigere; andre er soldater, der har været opsætsige imod deres foresatte eller har stjålet, og disse sidste kendes på, at de ikke bærer kokarde. Ofte, når jeg spadserede i Pærealléen og de nævnte fanger blev ført forbi, syntes jeg at kunne se på enkelte af dem, at de var nordslesvigere, og så følte jeg altid dobbelt for de stakler. Stakkels, stakkels Nordslesvig! lød det så inde i mig, jeg blev alvorlig og tavs, og mine kammerater kunne ikke begribe, hvad der fejlede mig. Jeg forklarede dem dog aldrig min tavshed; thi jeg kunne jo let være blevet bitter i min forkla- 
ring, da også mine kammerater hørte med til den nation, der har gjort os nordslesvigere så ulykkelige.

Atter forøgedes tallet af "fugleburets" beboere, en preussisk landeværnsmand stillede sig en dag som fange. Det var de gamle beboere påfaldende, at en menig kunne afsone en ham tilkendt straf som "Stubungsfangener«, og derfor havde vi alle en anelse om, at den ny kammerat ikke var en almindelig menig. Det var han heller ikke, han var præst, sognepræst et sted i provinsen Sachsen, og hans forseelse var, at han i 6-7 år ikke havde stillet ved kontrolforsamlingerne. For denne forsømmelse blev han af krigsretten idømt 16 dages fæstningsarbejde, men kejser Wilhelm benådede ham til 16 dages fæstningsarrest.

Den lille præst var stille og tålmodig, gjorde sig ikke bekendt med nogen af os andre og kom derfor heller ikke til at dele glæder og ærgrelser med os. Vi mærkede næsten slet ikke til ham i de 16 dage, han boede sammen med os, kun når han spadserede, lagde vi mærke til ham og til, at han var stolt af at have været soldat, thi han pyntede sig til hver spadseretur med erindringstegnet fra den tysk-franske krig, hvilket ellers ikke en eneste af de militære fanger gjorde, endskønt flere af disse havde både erindringstegn og ordener. Han holdt sig strengt forskrifterne for fangerne efterretteligt, hvilket vi andre ikke altid gjorde, og det gik os som de uartige børn, der ikke synes om de artige, vi kunne ikke lide den skikkelige præst, som aldrig risikerede at få en tilrettevisning.

En eftermiddag, da doktoren og jeg havde fået tilladelse til at spadsere i byen, gik vi forbi domkirken og så, at der på den store såkaldte domplads holdtes krammarked. Det var jo forbudt os at komme på offentlige spadsereveje, $\mathrm{i}$ restaurationer og så videre, men om markederne var der ikke specielt talt i instruktionen, og derfor sluttede vi, at det ikke var forbudt »ein Bißchen auf der Messe zu gehen«. Det morede os to fanger at bevæge os frit imellem så mange mennesker og at se på de mange glade markedsgæster, navnlig stod vi længe og glædede os over, hvorledes de pyntede landsbybørn, der var kommet til byen den dag, morede sig med at ride eller køre på karrusellen. $\mathrm{Da}$ vi kom forbi et telt, hvori en fotograf havde opslået sit atelier, råbte den vagthavende kasserer: "Guten Morgen, Herr Doktor!« (til mig!) og »Guten Morgen, Herr Oberamtmann! « (til doktoren!) - »treten Sie näher und nehmen Sie doch ihre Bilder mit!« De ny titler morede os, men kunne dog ikke bevæge os til at efterkomme opfordringen. 


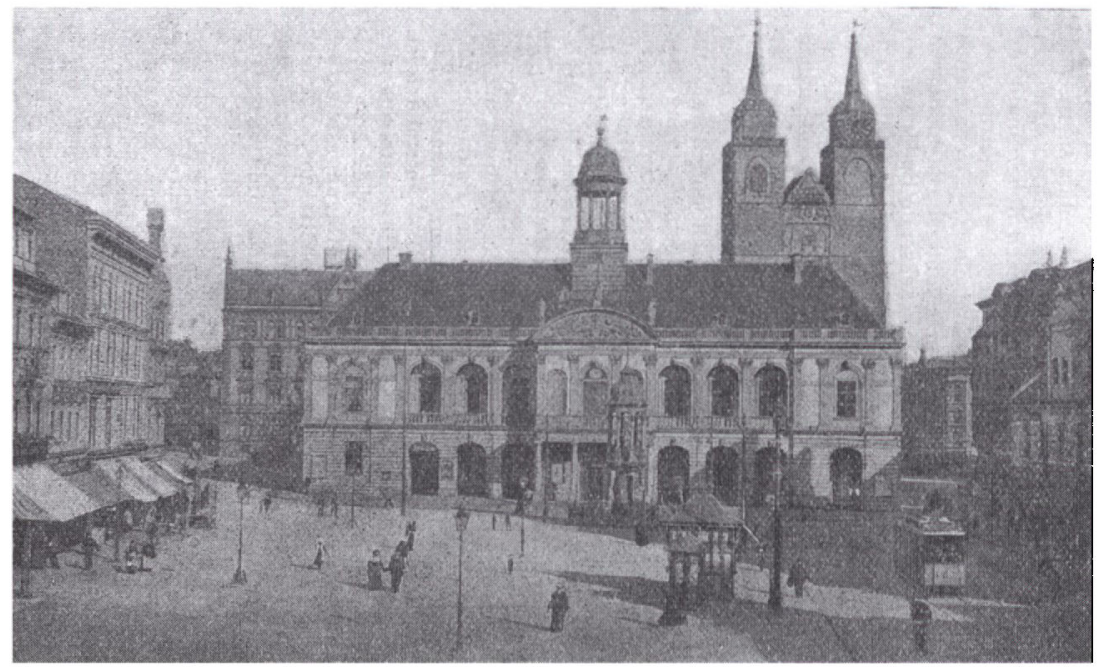

Torvet i Magdeburg (ca. 1905), hvor Gustav Johannsen gik tur med redaktor Dr. Guido Weiss - og blev tilbudt fotografering. Gengivet efter Woerl's Reisehandbücher. Illustrierter Führer durch Magdeburg und Umgebung. Hrsg. Leo Woerl. VII Auflage. Leipzig, 1905.

Da døren til domkirken stod åben og forskellige landsbyfolk gik ind for at se dens smukke indre, benyttede jeg lejligheden og gik med ind. Kirken er også umagen værd at se, både indvendig og udvendig. Den stolte sandstensbygning $i$ gotisk stil med de to smukke tårne havde allerede flere gange tildraget sig min opmærksomhed, nu fandt jeg også lejlighed til at se den indvendig, hvor de stolte søjler med de nydelige buer, glasmalerierne på vinduerne og forskelligt andet gjorde et mægtigt indtryk på mig. Magdeburgerne kunne med rette være stolte af at eje en sådan kirke. Meget i kirken minder om, at den har været en katolsk kirke, men det gør den ikke mindre interessant. Klokkerens datter forte de fremmede omkring i kirken og gav med forekommenhed oplysninger, når man spurgte hende om et og andet. Det var udmærket adspredelse for mig og timerne gik så rask, at jeg nær ikke var kommet hjem i rette tid. Doktoren, der kendte kirken, havde imidlertid moret sig "auf der Messe“, navnlig havde han glædet sig over nogle abekatte, »unsere Stammväter, nach Darwin«, som han spottende kaldte dem.

Hen imod oktober måned kom fangevogteren en dag ind til mig og fortalte, at fængselsbygningen skulle restaureres både indvendig 


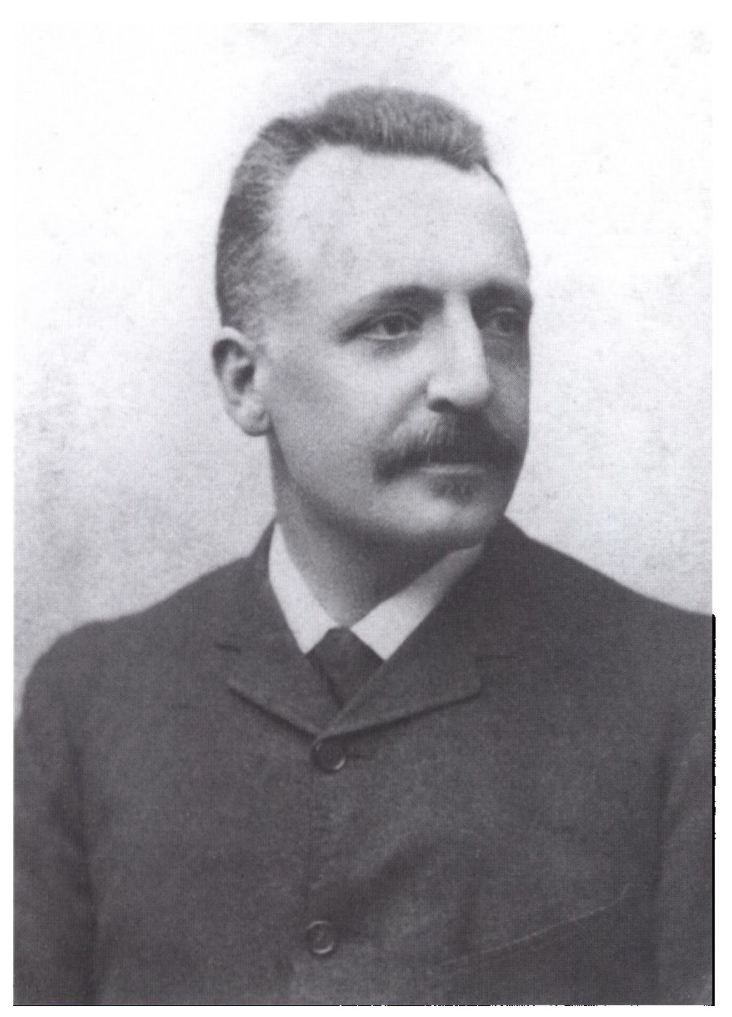

Hans Rudolf Hiort-Lorenzen (1832-1917) var sen af den beremte Peter Hiort Lorenzen, der "vedblev at tale dansk«. H.R. HiortLorenzen var avisen Dannevirkes ejer fra 1868 til 1879 og dets redaktør fra 1868 til 1875. I 1875 idemtes H. R. Hiort-Lorenzen otte måneders frestningsarrest, som han afsonede på frestningen $i$ Magdeburg $i$ samme bygning som Gustav Johannsen. Opholdet har $H$. R. Hiort-Lorenzen beskrevet $i$ sine Erindringer fra Sønderjylland, som udkom efter hans død $i 1919$. Foto: Institut for sonderjysk lokalhistorie.

og udvendig. En naturlig følge var, at vi fanger enten måtte sættes ind $i$ et andet fængsel eller også at restaurationen indvendig måtte ske stuevis. Dagen efter kom murfolkene og begyndte at skrabe på muren, der vender ud mod exercerpladsen. Da de havde skrabet det løse kalk af den usle bindingværksmur, begyndte de at kline nyt kalk på og penslede derpå hele muren over med en grå farve. Dette arbejde tog rigeligt to dages tid, men så kom der befaling til doktoren og mig om at rømme vore værelser og flytte over i nogle ledigtstående værelser på den anden side af korridoren. $\mathrm{Nu}$ begyndte murfolkene at udbedre væggene $\mathrm{i}$ vore gamle værelser, og efter dem kom en maler og strøg væggene med en grøn vandfarve, kun en gang, så den gamle farve - lyseblå - de fleste steder skinnede igennem og derved frembragte en ejendommelig skiddengrøn farve. Døre og vinduer blev ikke nyt opmalede, og da gulvet var fejet og en kone havde 
skuret det lidt med koldt vand, måtte vi atter flytte ind, for at man kunne tage fat på de midlertidig af os beboede værelser.

I omtrent tre uger havde vi derfor fra morgen til aften håndværksfolk i "fugleburet", og det var et morsomt virvar med flytteriet. Alt blev imidlertid gjort så usselt, at man deraf rigtig kunne slutte, hvor nødigt fæstningsvæsenet ville give penge ud for fængslet. Kun husets forside og fængselsværelserne samt vore møbler blev eftersete og restaurerede, og alt dette skete, fordi fæstningen i oktober måned skulle underkastes et eftersyn af en general. Heldigvis kom manden slet ikke ind i fængslet, thi ellers ville han med nogenlunde gode øjne absolut have måttet opdage, hvor let alting var gjort.

For resten er citadelfængslet i Magdeburg en af de usleste boliger for mennesker, jeg kender. Bindingsværksmuren er 6 tommer tyk, og der er næppe en dør eller et vindue, hvorigennem der ikke altid er en betydelig træk, så man både om vinteren og om for- og efteråret, ja selv om sommeren er udsat for forkølelse, snue etc. Kakkelovnene er store og meget uhensigtsmæssige, og når fangen ikke selv passer rigtig nøje på, at brændslet i kakkelovnen fornys hvert øjeblik, så kan han være vis på flere gange om dagen at sidde i et meget koldt værelse. Fangerne af civilstanden må selv sørge både for lys og varme, det er militærfangerne fri for; før var det også frit for de førstnævnte. At nogle af os knurrede over uroen med håndværkerne og at vi alle tilkendegav vor utilfredshed med den lette måde, hvorpå håndværkerne hjalp sig fra restaurationsarbejdet, forandrede ikke det ringeste, og snart støvede det lige så slemt som før, og alt var atter beskidt som førhen.

Jeg fik en dag brev fra redaktør Hiort-Lorenzen i Kobenhavn, der også har siddet i Magdeburgs fæstningsfængsel, ${ }^{6}$ og et af de spørgsmål, han kom frem med om sit gamle opholdssted, var: »Ellers er vel huset lige så beskidt og ækelt, som da jeg havde den ære at bo der?« Jeg kunne roligt svare ja, thi da jeg spurgte en embedsmand på citadellet, om "fugleburet" var blevet restaureret siden Hiort-Lorenzen boede der, svarede han: "Nej! Hvor kan De dog nære tvivl i den retning?»

Imidlertid var denne larm og støj med håndværkerne en afveksling i vort ensformige liv, og jeg må oprigtig tilstå, at jeg morede mig derover, hvor meget mine kammerater så også skændte på »die verdammten Kerle«. En af mine kammerater havde gjort sig den umage at gøre en tegning af »fugleburet«, endskønt det står i instruktionen, at ingen fange uden kommandanturens specielle tilladelse tør gøre 
tegninger og planer af opholdsstedet eller en del af samme. Denne bestemmelse mindede mig om, at selv Magdeburger Führer ikke indeholder tegninger eller planer af fæstningsværkerne, så jeg først slet ikke kunne finde citadellet på kortet over Magdeburg og omegn. Der var en hvid plet på det sted, hvor citadellet skulle have været betegnet, og alle vegne, hvor der måtte være antydet fæstningsværker, fandtes der hvide pletter. Dette skal være almindeligt på kort over byer med preussiske fæstningsværker. Politiet har alle vegne ordre til at forhindre, at der sælges kort med fæstningsværker på, en forsigtighed, der dog næppe fører til det resultat, som man har tilsigtet med forbudet.

Den fange, der ikke forstår at beskæftige sig, er naturligvis meget ulykkeligere end den, der kan få tiden til at gå med åndeligt eller legemligt arbejde. Det er imidlertid en falsk forestilling, når folk tror, at man $i$ et fængsel rigtig burde kunne arbejde. At læse aviser, ærgre sig over verdens dårligheder og den store masses uselvstændighed, dermed går den meste tid for politiske fanger. Min gamle kollega, doktoren, en gammel journalist, påstod, at han med den bedste vilje ikke kunne bestille noget alvorligt i fængslet, studenterne sagde det samme, og jeg måtte også tilstå, at jeg ikke følte mig oplagt til at bestille rigtig noget. Lider fangen oven i købet af den tanke, at han er forladt af sine venner, at forretningen hjemme går dårligt, at hans timelige velfærd måske står på spil etc., så er det rent galt med ham, og han falder da som oftest enten i en sørgelig sløvhedstilstand eller ser sig de mest afvekslende ulykkelige stemninger underkastet. ${ }^{7}$

En af mine kammerater bestilte bogstaveligt ikke andet end spise, drak øl og morede sig med fra morgen til aften at sidde på en stol, som han havde stillet midt i værelset, og kaste med en stor dolkekniv efter et brædt i gulvet. Han opnåede også en storartet færdighed i at sætte kniven ind $\mathrm{i}$ brædtet på det sted, som han sigtede efter. Han var en begavet ung mand, men fængselslivet trykkede hans sind således, at han virkelig kom til at lide af slem åndelig sløvhed, og dog havde han kun 4 ugers fæstningsarrest.

En anden medfange morede sig i flere uger med at drille skildvagten, dog således, at denne ikke kunne klage over ham. Det var om sommeren, og vi åbnede derfor straks om morgenen vore vinduer. Var fangevogteren ikke til stede, så gik den sidstnævnte fange hen til vinduet, tog en stok og lod den glide over jernstængerne, men altid kun når skildvagten på sin gang omkring huset var kommet et stykke 
forbi hans vinduer. Det gav en ejendommelig raslende lyd, og straks vendte skildvagten om og søgte at opdage, hvor den larmende lyd kom fra. Gerningsmanden var da regelmæssigt forsvundet fra vinduet og kom ikke igen, før skildvagten atter havde fjernet sig, men så begyndte også historien forfra. Dette drev fangen så længe, indtil han endelig selv var blevet ked deraf. $\mathrm{Nu}$ fandt han på at kaste med små sten, som han samlede på exercerpladsen, imod plankeværket, og atter havde han den fornøjelse, at skildvagten blev opmærksom derpå og søgte at udfinde, hvor larmen kom fra, hvilket dog aldrig lykkedes. En tredje fange havde den vane at gøre en stærk støj med at skubbe sine stole og sit bord frem og tilbage på gulvet, men også kun, når skildvagten ikke var i nærheden.

Ofte var skildvagten også selv skyld $i$, at fangerne drillede ham, thi det hændte ikke sjældent, at soldaterne viste en ligefrem uforskammet nysgerrighed og uden videre gik klods op til vinduerne og gloede ind til os, og dette opirrede enhver fange. Jeg kunne på ingen måde tåle denne næsvise nysgerrighed, og ofte har jeg åbnet mit vindue og spurgt den nysgerrige soldat om, hvad han onskede, hvilket for det meste havde til følge, at jeg blev fri for hans næsvise nysgerrighed. En fange er altid let pirrelig, men intet forstyrrer ham mere $\mathrm{i}$ sin ro end når han mærker, at nogen sniger sig hen til hans vinduer og prøver på at iagttage ham. Dette var nu altid meget vanskeligt for soldaterne, thi som bekendt bærer den preussiske soldat støvler, hvis såler er beslået med jernsøm, og disse giver altid en slem knirkende larm både på stenbroer og $\mathrm{i}$ sandet.

Her slutter Gustav Johannsens optegnelser fra fæstningsopholdet $i$ Magdeburg. Gustav Johannsen fik ved kejserlig benådning sin straf halveret og slap således ud igen $i$ begyndelsen af november 1879. Hans hjemkomst til Flensborg kom til at forme sig som et triumftog: Da han ankom til banegården var der samlet sd mange mennesker, der ville hilse ham velkommen hjem, at politiet næppe kunne opretholde ordenen. Pladsen foran banegården og hele den tilstødende Rådhusgade var fyldt med jublende mennesker. Det var vel nok byens populæreste mand, der vendte hjem igen. Gustav Johannsen blev $i 1881$ valgt til den tyske rigsdag, hoorefter han afhændede sin avis til Jens Jessen. 


\section{NOTER}

1. Vinhandler Aage Eduard Colding i Flensborg.

2. Gustav Johannsen var allerede sidst $\mathrm{i}$ 1870 'erne "Flensborgs ukronede konge«. Han var umådeligt populær i byen $o g$ besad en lang række forskellige tillidshverv $\mathrm{i}$ byens danske foreningsliv.

3. Opholdet i fængslet i Glückstadt i 1878 havde taget meget hårdt på Gustav Johanusen, der bl.a. tabte 22 pund på grund af den dårlige kost. Se René Rasmussen: Flensborg Avis 1869-1906. Flensborg, 1994.

4. Navnet er anonymiseret i Gustav Johannsens tekst.
5. Dr. Guido Weiss var redaktør af »Die Waage «.

6. Hans Rudolf Hiort-Lorenzen var udgiver af avisen Dannevirke 1868-1879. Han sad otte måneder på fæstningen i Magdeburg i 1875-76. Se René Rasmussen: H.R. Hiort-Lorenzen og Dannevirke 1868-1875. Aabenraa, 1993.

7. Gustav Johannsens Flensborg Avis var under hans fravær kommet $i$ alvorlige økonomiske problemer, og der var udbrudt uenighed blandt hans venner hjemme i Flensborg. Se René Rasmussen: Flensborg Avis 1869-1906. Flensborg, 1994. 